\title{
GOSPELING THE GOSPEL IN ACTS ${ }^{1}$
}

\author{
Scot McKnight \\ North Park University \\ Chicago IL, USA
}

\begin{abstract}
The task of evangelism ('gospeling') is no less demanding and difficult today than it was in the time of Peter and Stephen and Paul. It is also in no less need of creative adaptations to audience. Perhaps what we need more of is the boldness (Acts 2:29; 4:13, 29, 31; 28:31) that came upon them through a fresh blowing of the Spirit. Perhaps the absence of resurrection theology in much of gospeling today is to blame for the lack of boldness. We need to recover more of the early Christian resurrection gospel and we need less of the theodicy-like focus Anselm and the Reformers gave to atonement theories.
\end{abstract}

Key Words: Luke-Acts, Gospel, Early Church, Speeches in Acts, Emerging Church

\section{Introduction}

There was a time that the one thing all orthodox Christians generally agreed on was the gospel. But issues have arisen in the last generation that has shifted so many factors that the gospel itself is in need of careful clarification and even re-examination. I will use the words of Brian McLaren (2007:23), an American emergent leader, and call what is going on a deep shift and, if he really is accurate that there is a deep shift, then everything must change.

\section{Elements leading to a Re-examination of the Gospel}

There are ten elements in this deep shift that leads us as Protestants back to the New Testament to start all over again. I can't develop these, so let me mention them briefly.

- First, understanding the work of God as missio Dei (McKnight 2007:135-136). Mission is, primarily and ultimately, the work of the Triune God, for the sake of the world, a ministry in which the church is privileged to participate (Bosch 1991:392). I learned this from David Bosch (1991:389-393) but missio Dei is involved in important ways in all areas of New Testament study (see McKnight 2007:137-141).

- Second, heaven. Most Christians' perception of heaven derives more from Platonism (or Neo-Platonism) or Dante or John Bunyan or stories heard in sermons than the Bible or the ancient Jewish world (Wright 2008:3-30), and the recent book by Tom Wright, Surprised by Hope (2008), rooted as it is in his larger book, The Resurrection of the Son of God (2003), is re-arranging how we understand both life now and life then in much more earthy categories.

1 This article is based on an oral presentation given by Prof Scot McKnight at a 'Missionary Church in Acts' Conference held at Stellenbosch University, 29-30 May 2009. Retaining the presentation style, Dr Marius Nel, New Testament research fellow at Stellenbosch University edited Prof McKnight's paper for publication, with his permission. 
- Third, conversion. There has been a holy disquietude in many circles with the 'altar call' and 'decision' approach to conversion. There has also been disquietude about the rather bland socializing processes at work in many liturgical/catechetical traditions, with some clear calls to re-examine the whole conversion process (McKnight 2002:5-14). And this not only as a result of careful studies on the process of conversion, but also because we have become more aware of Jewish proselytism and the potency of nurturance into the faith (McKnight 2002:5-7, 172-173).

- Fourth, reading the Bible as Story has lifted the veil for many. Instead of distilling the propositions and forming a systematic theology, the power of story has led many to see the Bible's narrative arc as the Bible's theology (cf. Greene \& Robinson 2008:101-131).

- Fifth, Jesus' kingdom vision (cf. McKnight 2007:9-14). The so-called Third Quest embraced a Jewish Jesus (Brown 1992:337; Dunn 2003:85-92) and this led more and more theologians and pastors to make 'kingdom' central to preaching, to teaching, and to missional work (McLaren 2006:117-196). The shift from a Pauline-Romans framing of the gospel to a Jesus-kingdom gospel can, however, be staggering for some (Frost 2006:29; Nel 2009:41).

- Sixth, somewhere along the line church was being deconstructed at the same time it was being reconstructed. Careful, and some not so careful, studies about 'church' and about 'denominations' and about 'institutional religion' are leading to both reformulations of what 'church' is and to rearrangements of what church will be (e.g. Viola, F \& G Barna 2008).

- Seventh, sin. The older, Reformed sense that sin can be reduced to moral rebellion leading to guilt before an all-holy God has been expanded to systemic and personal proportions. Three books that brought this home to me are by Cornelius Plantinga, Not What's Supposed to Be (1995), Ted Peters, Sin (1994), and Mark Biddle, Missing the Mark (2005). A potent deconstructive force came from women (e.g. Judith Plaskow) who argued that if sin is defined by males, are women being held in check by such male definitions (cf. Thiselton 2007:303-304)? Need I say it? The moment one reframes 'sin' one reframes more elements than we have time to enumerate (McKnight 2007:46-48).

- Eighth, Jesus. In the 1980s historical Jesus flew into orbit at an alarming pace, and it seemed every month a new Jesus arrived on the scholar's doorstep (see Witherington 1997 for an overview of the Third Quest for the historical Jesus). Once the dust settled, we realized that Jesus re-framed involved both a reframing of 'gospel' and, in fact, a reframing of 'Christianity' itself.

- Ninth, justice and justification. It probably goes back to Krister Stendahl (Wright 2009:12), who boldly suggested that we can't divorce 'justification' from 'justice.' This insight lead to the New Perspective and a lot of changes (see Wright 2005), not the least of which involved the meaning of 'gospel' as somehow involving the inclusion of Gentiles (Wright 2009:14-21).

- The tenth element is gospel itself. What does it mean? Everything changes when the first nine shifts lead to a re-examination of gospel. But, as Protestants we want to go back to the Bible and see how the earliest Christian 'gospelers' understood the gospel. 


\section{Acts and Mission}

The story of Acts, which is part two of a two-part narrative, ${ }^{2}$ is the story of the gospel spreading from a hideout in Jerusalem, with just a few disciples gathered out of both fear and hope, to a hideout in Rome, with a man named Paul who had absolutely no fear.

It's the story of gospeling as Luke takes us from Jerusalem to Caesarea Maritima to Syrian Antioch (cf. 11:19-21) to Pisidian Antioch to Athens and then on to Rome. The Roman citizen from Tarsus hardly saw captivity as an obstacle to reaching Rome with the gospel (Barrett 1998:1253), even if he is still involved with intramural debates with fellow Jews before he gospels Gentiles (cf. 28:23-29 then 28:30-31). One has to wonder if Nero is mocked when Luke tells us, in a triumphal entry like description, ${ }^{3}$ that swarms of Christians welcomed Paul into Rome (Acts 28:11-16). In almost Stoic-like fashion Paul seems totally unconcerned with physical danger (28:20). He spent his days in prison with Jewish crowds gathered at his door as he "witnessed to them from morning till evening, explaining about the kingdom of God, and from the Law of Moses and from the Prophets he tried to persuade them about Jesus" (28:23). And there is nothing short of bravado in the tone of Luke's final verse when he says that Paul "proclaimed the kingdom of God (cf. 1:3) and taught about the Lord Jesus Christ - with all boldness and without hindrance!” (28:31; cf. 2 Tim 2:8-9).

Act 1:8's prediction of the gospel going 'to the ends of the earth' has now been fulfilled and so has the preaching of kingdom by John the Baptist and Jesus (Luke 3:3; 4:18-19). Anyone who knows the history of Israel knows that Jonah is the typical response to the Gentiles in ancient Israel - for Israel was not what today is called a missionary religion (Wright 2006:24). That the earliest Christian movement became not only a missionallyshaped movement, expanding the gospel across the Roman empire, does not surprise anywhere near as much as does the overt extension of the gospel to Gentiles. There have been all kinds of explanations of what precipitated the missionary impulse in the early church - not the least of which are things like persecution and the glory of Gentile Godfearer responses in synagogues (Stark 1997:58, 67-68, 163-189) - but the issue is how the earliest Christians responded to the success. Not all of them thought it was such a good idea. We need not detain ourselves for this discussion except to observe that it is the extension of the gospel through gospeling to Rome that occupies the attention of the Book of Acts (cf. Bock 2007:759). This is how the Book of Acts closes and one of the most important things we can keep in mind when we read Acts is that this text is overwhelmingly missional in design.

\section{Gospeling in Acts}

I will approach the missional hermeneutic of Luke by examining the theme of gospeling in Acts by making suggestions about how the gospel was understood in Acts before concluding with the implications of early Christian gospeling for gospeling today. Instead of pursuing an inductive display of the gospeling in Acts and how each gospeling sermon responds to its context and fits into the literary plan of the Book of Acts, I want to offer some highlights of the gospel preaching of Peter (4.1), Stephen (4.2), and Paul (4.3).

\footnotetext{
For an examination of the evidence for the Lucan authorship of Acts see Bock (2007:15-19.)

This is the sense of the Greek èlthan eis apantēsin émin in Acts 28:15. The noun apantēsis was almost a technical term for the official welcome of a visiting dignitary by a deputation, which went out from the city to greet him and escort him on the last part of his journey (Bruce 1988:502).
} 
I am not equating the words of Acts with a transcript of Peter's words. History-writing and reporting of speeches held to different standards then but neither do I want to suggest that Luke, or whoever wrote Acts, just made things up. The style is Luke's, the substance more or less not. ${ }^{4}$

\subsection{The Gospeling of Peter in Acts}

I begin by quoting the most pregnant of summaries of Peter's gospeling, now found at Acts 5:29-32: Peter and the other apostles replied: "We must obey God rather than human beings! (cf. 4:19). The God of our ancestors raised Jesus from the dead - whom you (cf. $2: 36 ; 3: 14-15 ; 4: 10$ ) killed by hanging him on a cross (cf. Deut $21: 22-23$ ). God exalted him to his own right hand as Prince and Saviour that he might bring Israel to repentance and forgive their sins." What we have in this summary is (1) an appeal to the Story of Israel now come to fulfillment in the Story of the Messiah, and we see this in the "God of our ancestors". This theme is more than a 'gospeling' theme; the scriptural plan of God coming to realization in Jesus Christ, in fact, is central to the whole framing of Luke-Acts (cf. Meek 2008:133). (2) The Story-transforming significance of the resurrection of Jesus; (3) a pointing of his finger at those who crucified Jesus, and here Peter lays blame on 'you' and the 'you' of that context is the Jewish priestly establishment (cf. 5:17-28) (Kee 1997:81). With the cross and resurrection now factored into the summary, Luke moves to (4) the act of God in raising Jesus to an exalted place to vindicate and establish him as the 'Prince and Saviour' of Israel; (5) the movement from cross to resurrection to exaltation leads to the statement that God did this "that he might bring Israel to repentance and forgive their sins." Finally, (6) Peter lays claim to being a witness ( $\mu \alpha \rho \tau \nu \rho \varepsilon \varsigma)$ alongside the Holy Spirit, who has been given in Pentecost-like fashion to those who 'obey' God. Peter gospels a number of times in Acts, including Acts 2:14-39, 3:12-26, 10:34-43 and 11:5-18.

First, Peter emphasizes the Story of Israel as the God-ordained Story that pointed to and comes to completion in the Story of Jesus of Nazareth. Thus, in Acts 2:13-21, Peter quotes Joel 2:28-32 and Pss 16:8-11 and 110:1. These texts essentially return to the Tanakh in order to point forward to what has happened in Christ and at Pentecost (Meek 2008:112113). In fact, one's hermeneutic might be that Jesus' resurrection and the gift of the Holy Spirit at Pentecost led the earliest Christians to re-read and re-interpret Tanakh from a singularly new perspective. In Acts 3:22-23, Peter quotes Deuteronomy 18:15, 18-19, here showing that Jesus is the expected Prophet to whom one must listen or suffer extirpation. At Acts 3:25 he quotes Genesis $22: 18$ or $26: 4$ to establish the Abrahamic origins of the

$4 \quad$ The Book of Acts is Luke's account and it was Luke who sketches the gospeling of Peter and of Stephen and of Paul. Luke-Acts scholars have for a long time pointed out the noteworthy Lukan style features that are found in these speeches. Sometimes, however, there is an implicit logic at work that moves like this: Speeches are in a style; that style is Luke's; therefore, they are not Peter's, Stephen's or Paul's. In other words, there is a logic that suggests if something is stylistically Lukan its substance is both Luke's and not the purported gospeler. This logic, however, fails. Nelson Mandela's autobiography, Long Walk to Freedom, might give us a first-hand account of his life, but something said by Desmond Tutu about Mandela might not only be Tutustyle but also substantively factual or accurate. Hence, Lukan style does not disprove historical accuracy in the substance that has been stylized (Achtemeier, Green \& Thompson 2001:262-263). Moreover, the intent of Luke might be to report the intent of Peter or Stephen or Paul even if Luke creatively constructed what was said. According to Polhill (1992:44) Luke followed the methodology described by Thucydides in that he gathered information from eyewitnesses, and relying on his own memory where possible, provided as accurately as he could the 'gist' of what was said (cf. Bruce 1974:53-68). All this to make two points: first, that the style of Peter's and Paul's gospelings are similar and, second, there are some notable differences. This might not help the historian in determining if he or she can lay all the weight on Lukan creativity, but it does make the historian honest. 
gospel (Bock 2007:180-181), unwittingly evidently bringing an anticipation of the Gentile mission and use Abraham in a way that Paul did in his own writings. Finally, in Acts 10:43 Peter finishes off the gospeling event at Cornelius' house by saying that 'All the prophets testify about' Jesus.

Thus, as Wilckens (1974) made clear in his Die Missionsreden der Apostelgeschichte, the gospeling sermons of Peter and Paul are designed to take the saving events of Jesus and make them word events - and each turning point in Acts must make this clear. They make clear the salvation-historical significance of Jesus in Israel's Story and God's plan. Second, Peter's gospeling involved telling the full Story of Jesus Christ, including his life, his death, his resurrection, his exaltation, the gift of the Holy Spirit and his second coming. The reason we have to say this is because Eastern Orthodoxy, Roman Catholicism, and Protestantism have more or less converted the life of Jesus into Good Friday. Not so in the early gospeling (cf. Acts 10:36-42) where we see the whole life of Jesus (McKnight 2007:54, 70-78).

That message spread throughout Judea, beginning in Galilee after the baptism that John announced: how God anointed Jesus of Nazareth with the Holy Spirit and with power; how he went about doing good and healing all who were oppressed by the devil, for God was with him. We are witnesses to all that he did both in Judea and in Jerusalem. They put him to death by hanging him from a tree; but God raised him on the third day and allowed him to appear, not to all the people but to us who were chosen by God as witnesses, and who ate and drank with him after he rose from the dead. He commanded us to preach to the people and to testify that he is the one ordained by God as judge of the living and the dead. This text is not quite complete, but if one adds together what we find in Acts 2:22-35, 3:13-15, 19-21, and 10:37-42, we discover that Peter preached the whole Story of Jesus as Messiah.

The gravity of emphasis in Peter's gospeling, similar to others in the Book of Acts, is the resurrection, which of course implies Good Friday but is more than that. When Peter and John were imprisoned in Acts 5, the angel miraculously released them so they could go back to the Temple and give this message: "Go, stand in the temple and tell the people the whole message about this life" (5:20). This 'life' is probably, as Barrett (1994:284) observes, the life Jesus gives because he is the 'Author of life' (3:15). In other words, we are looking at an angel directing them to announce resurrection gospel. Alongside this resurrection emphasis, though, is a clear blaming of the temple establishment for rejecting Jesus, and a good example of this is 3:13-15.

It needs to be observed in passing, especially for those of us who draw our ideas from the Reformation, that Peter's gospel has no atonement theology at work in it (Conzelmann 1960:200-201). Jesus lived and died and was raised, and that's enough for Peter. Those who repent and who believe and who get baptized are forgiven and receive the Holy Spirit, but Peter does not tell us how. In addition, Peter's gospel is not just the life and death and resurrection of Jesus. For Peter, Pentecost, which must be connected to the ascension and exaltation of Jesus, means divine power for the Story of Jesus and his people. The exalted Jesus sends the Spirit (2:33). Even if there is a theological reason for neglecting the Holy Spirit - after all the Spirit bears witness to Jesus Christ instead of to the Spirit (cf. John 15:26) - there are no reasons for missing how important the Spirit is to the Book of Acts (Jervell 1996:43-54; Meek 2008:105-106). From 1:8 on, the Spirit shapes everything important: Jesus had the Holy Spirit (10:38), Pentecost brings the Spirit for all (2:1-4), the Spirit endowed prophesies and visions and dreams $(2: 17-18 ; 11: 28 ; 13: 4 ; 21: 11)$, and the repentant believer receives the Spirit along with forgiveness of sins $(2: 38 ; 5: 32 ; 8: 15-17$; 
10:44-47). For our purposes, gospeling is Spirit-inspired witness to Jesus when done right (Acts $4: 31$; cf. 6:10; 7:55; 13:4, 9; cf. 16:6-7; 19:6).

Pentecost both prompts the first gospeling in human history and becomes paradigmatic for what gospeling can accomplish. In brief, Pentecost and its gospeling creates community of all kinds of people and it does this because Pentecost re-establishes the covenant as the new covenant, undoes Babel (Gen 11:1-9), challenges Jerusalem- and Rome-based empire structures that are rooted in various forms of conformity, and Pentecostal gospeling forms an embodied reality of koinonia that transcends national and language differentiation, not by abolishing distinction but by transcending distinction to form a unity within diversity (2:5-12, 42-47; 4:32-35) (McKnight 2007:74-78).

The image then is of multiple languages and peoples all praising the same God. Moreover, Pentecost and its gospeling create a new social network. Bosch (1991:118) has observed that the theme of the poor is less evident when we move from the Gospel of Luke to the Book of Acts. But, perhaps it is wiser to think that Pentecost and Spirit-empowered community life replaces concern with the poor because they both encompass concern for the poor as a community of goods and through almsgiving transcend them by extending Jesus' concerns to include Gentiles (cf. Acts 10:34-38).

Peter reads a Bible that leads him to see God at work guiding the Story of Israel into the Story of Jesus, who is Israel's true King and the Lord over all (cf. Also 2:39; 3:25-26; $10: 44-47 ; 11: 16-18)$. Peter knows this because God raised Jesus from the grave. There are other terms used for Jesus by Peter, including servant $(3: 13)$, the holy and righteous one (3:14), the author of life $(3: 15)$, and the prophet $(3: 22-23)$. But these supplement his two major terms, Messiah and Lord. It is here that we need to observe again that gospeling Gentiles was a radical step - even if it is anticipated in Acts 2:17-21 and 3:25 in Peter's sermons, implicit in the Hellenist Stephen, and if Philip's gospel encounters with the Samaritans and the Ethiopian eunuch reveal the direction we are headed once we get to Paul, it is Peter's gospeling of Cornelius, with angelic softening of Peter's reluctant covenant heart, that forms the crucial breakthrough (Bock 2007:380). The gospel is been set loose from this episode on. It will find its home in the center of Rome, the epicenter of the world for Luke-Acts.

Peter's gospeling includes the call to respond. In Acts one might make a distinction between apologetics and gospeling on the basis of whether or not there is a call to respond. As we will see shortly, Stephen's speech has no such call to respond, but in four of Peter's gospeling events we see this summons to respond. There are three integrally related acts for Israelites and Gentiles who respond to gospeling: they are to believe and to repent and to be baptized.

Peter summons people to believe in Acts 10-11 (cf. 10:43 and 11:17). After Peter explains the event of the Holy Spirit at Pentecost through the lens of the Story of Israel, and that means Joel 2:28-32 (Hebrew 3:1-5) and two Psalms of David, Luke tells us that those who heard Peter 'were cut to the heart' and asked what John the Baptist's audience asked, "Brothers, what should we do?" (2:37; cf. Luke 3:10-14). Peter's words are famous (Acts 2:38-39): "Repent, and be baptized every one of you in the name of Jesus Christ so that your sins may be forgiven; and you will receive the gift of the Holy Spirit. For the promise is for you, for your children, and for all who are far away, everyone whom the Lord our God calls to him." In Acts 3:19-21, Peter says: "Repent therefore, and turn to God so that your sins may be wiped out, so that times of refreshing may come from the presence of the Lord, and that he may send the Messiah appointed for you, that is, Jesus, who must remain in heaven until the time of universal restoration that God announced long ago through his 
holy prophets." And in Acts 10:47-48, while Peter was still preaching, the Holy Spirit came down afresh on the audience, extending Pentecost to Gentiles, and Peter asked this question: Then Peter said, "Can anyone withhold the water for baptizing these people who have received the Holy Spirit just as we have?" So he ordered them to be baptized in the name of Jesus Christ. Then they invited him to stay for several days.

Acts 2:38 achieves a balance in the two matters of repentance and baptism, which I take to be instances of faith. Acts 3 mentions only repentance while Acts 11 focuses on baptism and does not mention repentance. ${ }^{5}$ In light of the Lukan two-volume story, though, one would have to say that repentance - from the days of John the Baptist to the days of the apostles - is the expected response, along with baptism as the embodiment of confession, incorporation into Christ and the community by faith, and the washing away of sins (cf. Ferguson 2009:170). These two are expressions of faith in Jesus Christ as trust in who he is and as God's redemptive agent. Peter does not mention circumcision when it comes to the proper response to the gospel when he gospels the Gentiles in the context of Cornelius. While the sketch of what was required of proselyte conversion to Judaism is not entirely clear, one thing that would have been nearly impossible to avoid for a Gentile male was circumcision (Ferguson 2009:177). That act was the 'seal' of the covenant in Jewish thinking (cf. Gen 17) and it cannot have been missed had Peter permitted Gentile conversion into the Jesus community without requiring the kosher blade. That the issue emerges in Acts 15 does not surprise; that it does not emerge in Acts 10-11 does surprise. Luke has perhaps washed history clean of that debate so he can assign the necessity of circumcision to his opponents, or perhaps circumcision was as necessary as we think or, which is how Luke tells his story, Peter saw the gift of the Holy Spirit on the gentiles and said, "If repentance and baptism draw the Spirit down from the heavens then we need nothing more."

Peter's gospeling made promises to those who did respond properly. While some today see 'gospeling' as no more than declaring the Story of Jesus or that Jesus Christ is Lord, Peter sees gospeling as something that is shaped toward an audience and that summons individual persons to respond for salvation. There are a few terms Peter uses when he gospels for what a proper response brings. Repentance and baptism bring forgiveness of sins $(2: 38 ; 3: 19 ; 10: 43)$, they bring the Holy Spirit $(2: 38-39 ; 10: 44-47 ; 11: 16-18)$, they bring what Peter calls the 'times [plural] of refreshing' $(3: 20)$ and which is probably best understood as ongoing realizations of God's gracious redemption and relief as seen in such things as forgiveness and the power of the Spirit and miracles and the spiritual-social solidarity of Acts 2:42-47; 4:32-35 as well as the ongoing expansion of the gospel to include even Gentiles. ${ }^{6}$

To summarize: for Peter (as presented by Acts), gospeling involved telling Israel's Story as one that pointed to and came to its fulfillment in the life and death and resurrection

5 Those who'd prefer not to mention repentance can appeal to Peter as can those who prefer repentance. And those who prefer adult baptism can appeal to him, too, while those who prefer paedo-baptism cannot (Ferguson 2009:169-170).

6 Cf. Acts 10:36: "You know the message he sent to the people of Israel, preaching peace by Jesus Christ - he is Lord of all." Here Peter says he 'gospels peace.' This peace comes 'through' or 'by' Jesus Christ. I take this expression to be a twin to some Pauline theology and so read it as the kind of peace between Jews and Gentiles that was both anticipated in the Abrahamic blessing (Gen 12:1-3) and yet never worked out pragmatically until the incorporation of Gentiles into the church. This more sociological (both with God and with others) instead of existential sense of peace, ushers us into the New Perspective on Paul, where there is given a more corporate and history-of-redemption framework for understanding early Christian thinking (cf. Wright 2009:8-21). 
and exaltation of Jesus Christ (cf. Meek 2008:133), along with the gift of the Spirit, it involved pointing to the central significance of Jesus as Messiah and Lord, it involved summoning his audience to repentance and baptism and faith, and it involved promising them that such a response would bring forgiveness of sins, the Holy Spirit, 'times of refreshing' and peace.

\subsection{The Gospel of Stephen in Acts}

Bible scholars have long been educated into a method of reading the Bible called salvation history. As a college student I became aware of salvation history by reading Ladd: $A$ New Testament Theology (1974) and by reading Ridderbos, Paul: An Outline of His Theology (1975). What has continued to amaze me over more than three decades of biblical study is how little impact salvation history has on evangelism or what I prefer to call 'gospeling.' Instead of trotting out Israel's Story when the gospel is explained, most tend to narrow everything down to personal sin and to personal guilt and to personal redemption and to personal response (McKnight 2007:11). If anyone in the New Testament confirms the gospel is a narrative arc as found in Israel's history as Israel's Story, Stephen does as he creates an indictment against his accusers (Bock 2007:276-277). Stephen 'gospels' without summoning people to respond with faith, repentance and baptism and he does so by showing that God can bring good out of evil because God's plan goes on. In the context of the Book of Acts, one will want to observe that the heated rhetoric of Stephen's speech begins a break with the Judaism of Jerusalem: Stephen is a Hellenist, Stephen leads to the conversion of Saul, and from that time on the gospel begins to spread to the Gentile world.

Because Stephen's intent is not to draw out a response, some prefer today to call Stephen's speech an apology or say it is a piece of apologetics (cf. Alexander 1999:32). In fact, Stephen's speech is accusatory and didactic apologetics. If he partly defends himself, he concludes not with an appeal to see his innocence but with a powerful set of words that accuse his opponents of covenant infidelity. Within that accusatory speech we glean the gospel of Stephen, about which now I want to make just a few remarks.

First, from front to back Stephen's gospel is a narrative of Israel's Story as it comes to its climax and fulfillment in the Story of Jesus (Kee 1997:95-102). Stephen traces Israel's Story from Abraham to Joseph to Moses and to Solomon (7:2-47). Solomon sets him off, and he turns into a rant against the Temple establishment (7:48-50). This leads him, in deuteronomic fashion (Bock 2007:277), to situation Jesus' death into a context of the leaders' covenant infidelity, a trait Stephen finds typical (7:51-53).

Second, in line with Peter (4.1) and Paul (4.3), Stephen understands the Story of Jesus through the lens of an unjust crucifixion that was reversed with power when God raised Jesus from the dead and exalted him to the right hand of God (7:52, 55-56). At the core of early Christian gospeling, was the unthinkable: God had taken a dead body, made it come back to life, and had exalted that very person to his right hand at the Throne of God (cf. Kee 1996:33-34). Stephen's perception, unlike Peter's use of psalms of David, emerged from Daniel 7's exaltation of the Son of Man before the Ancient of Days and Luke has Jesus standing at the right hand of God, perhaps a way of saying that Jesus is rising to enact judgment (cf. Isa 3:13).

Third, like Peter (4.1), Stephen's gospel theology works with a christology, and Stephen combines Son of Man - here a title of exalted authority - with Peter's prophet-like-Moses (cf. 7:37). In addition, Jesus is the 'Righteous One,' a term designating Jesus' utter innocence (7:52) (Marshall 1980:147). Stephen's defence, instead of appealing to the 
audience to repent and to trust Jesus and to be baptized for the forgiveness of sins, turns on the audience in potent language that condemns the Temple establishment and blames it for covenant infidelity. One is led to wonder if some early Christian gospeling faced a fork in the road and, at times, turned into a accusation against those who had crucified Jesus (Bock 2007:269, 307). Inherent to gospel theology was condemnation of those who had betrayed Jesus ("you killed him but God raised him up").

\subsection{The Gospel of Paul in Acts}

Paul's gospel in Acts is essentially that of Peter and, in some ways, that of Stephen. The basics are the same: we find the Story of Israel coming to a climax and fulfillment in the Story of Jesus (13:17-22, 32-37), though Paul's Story of Israel is more positive than Stephen's. We find a similar focus on the death of Jesus as an act of injustice (13:24-25), with Paul shifting blame slightly toward the people (13:27-28), and the resurrection as an act of God's vindication of Jesus (13:30-31, 32-37). And this gospeling of Paul leads to, or is rooted in, a Christology in which the vindicated Jesus is seen as the Davidic Saviour (13:23, 33-37) (Barrett 1994:636-637, 647-649). And, Paul's gospeling leads to a summons to repent (13:40-41) for the forgiveness of sins (13:38-39).

In the two major gospelings of Paul in Acts (13:16-41 and 17:22-31), we do not hear tones of the exaltation of Christ to the right hand of God and we hear nothing of the gift of the Holy Spirit. But one would be hard-pressed to deny that Paul's gospel is much the same as Peter's. That both refer to Psalm 15:10 which notably connects the two apostles (cf. Acts 2:25-28; 13:35).

Paul's gospel is more emphatically adapted to and for Gentile audiences. Peter leaned toward and then learned that the gospel was also for Gentiles; Paul had discovered that to be true he was now pushing the gospel into the Gentile world. His theological platform was composed of a scriptural understanding of history and a relentless commitment to monotheism in the face of being charged with belief in 'foreign divinities' $(17: 18)$, precisely what led to the execution of Socrates. Even a Gentile audience did not stop Paul from seeing the sweep of history through the scriptural Story of Israel. The audience of Paul's gospeling in Pisidian Antioch (13:16-41) was 'Israelites and God-fearers.' We can assume they knew enough Scripture to know what Paul meant, but on the Areopagus, where Paul is clearly gospeling to Gentiles with no knowledge of Israel's Scriptures (Bruce 1988:335), Paul tells history through the lens of Israel's history - minus the election and covenant. He observes idols, assumes monotheism and tells us that God is creator, appealing to Genesis 1-2, and that this God does not dwell in physical structures, and this like Stephen's defence (cf. Acts 7:48). Moreover, he appeals again to Adam in the "from one ancestor God made all nations to inhabit the whole earth" (17:26). But clearly Paul is adapting the gospel to his audience (Bock 2007:558-559, 566-568).

I would point to two features of how Paul adapts the gospel on the Areopagus, the centre of Greek culture, wisdom and philosophical greatness. Athens was then not what it had been (Bruce 1988:329; Barrett 1998:826), but it is there that Paul focuses on God as the invisible creator of all of creation and who is therefore common to all religions (17:24-30), and he appeals to what could be seen as a praeparatio evangelica. By this I mean that there is something in each human being that gropes for God and that groping instinct comes from God and leads to God. Paul discerns this groping in the idols around Athens, especially the one 'To an unknown god' (17:23). Thus, Acts 17:27-28 which climax in a quotation from the third-century BCE poet, Aratus: "So that they would search for God and perhaps grope 
for him and find him - though indeed he is not far from each one of us (cf. Bock 2007:568)." For "In him we live and move and have our being"; as even some of your own poets have said, "For we too are his offspring." Paul's words - as Luke constructs them are notable. As Johnson (2006:319) has put it: Luke "simply shows Paul picking up the inchoate longings of this 'exceptionally religious' people and directing them to their proper object." Adaptation runs through the whole gospeling event. Most notably, Paul does not speak directly either of Jesus Christ or of the crucifixion of Jesus Christ when he is on the Areopagus.

The apostle Paul of Galatians and Romans and 1 Corinthians doesn't ever seem to drop the cross from the gospel, but the Paul of Acts 17:30-31 does. To quote Dunn (2008:688): "In short, the Christology is subordinated to the theology; the developing christological distinctives of Christian faith are subordinated to the prior task of winning appropriate belief in God." Still, the entire weight of the gospel message is carried by the resurrection as an act of the one God. It needs to be observed that Paul's notion of 'resurrection' is not re-cast in terms of the Platonic 'immortality of the soul,' and Wright (2003:28-31) made this point over and over. Resurrection as 'life after death' is not the same thing as the immortal soul carrying on after it escapes from the body.

What Paul says about resurrection was not a touchstone with the Athenians; it was a sharp-edged difference. Resurrection can be given too much attention. The actual weight is carried by Christology of which the resurrection is part and which proves that God is with this one man. Paul's words are that God will someday judge the whole world "by a man whom God has appointed" (17:31). Resurrection, no doubt, implies death - and in the narrative arc of Luke-Acts that death is the crucifixion - but it is noteworthy for a gospeling passage that Paul does not mention the crucifixion and there's not a trace of an atonement theory at work in his gospeling in Athens. One element in Acts 17, namely that God will finally administer justice through the one who suffered injustice (17:31; cf. 11:28), leads me to think the narrator of this text thinks of the death of Jesus as something dished out with injustice by the Jewish Temple establishment and for which the philosophers on the Areopagus were not being held accountable (just yet). This might explain why he does not bring up the crucifixion - it simply wasn't their problem.

Paul's gospeling summons his audiences, Israelites, God-fearing Gentiles and curious Athenian philosophers, to believe and repent. In Pisidian Antioch, Paul summons the audience to believe, and here Paul, surprisingly enough, sounds very much like Paul (13:38-39). I translate it as: "Let it be known to you, [my] male brothers, that through this person forgiveness of sins is proclaimed to you. [And] by this one person everyone who believes is justified [even] from all those [sins] from which you were not justified by the Torah of Moses." Not only does this sound like Paul's famous anti-works-of-the-Law rhetoric, but also similar to Romans $4: 25$ in that justification is tied to resurrection. The proper response to the Pauline preaching, like that of Peter, is to believe. And to repent. While the warning at the end of the Pisidian Antioch gospeling (13:40-41) does not mention repentance directly, it does appear in Acts 14:15-17 and especially in what he says to the philosophers on the Areopagus (17:30).

The Athenians' groping is not enough. Paul wants that groping to become what it wants to be: a grasping that generates repentance. Now that God has brought history to this point and now that everyone knows, everyone must repent to be granted forgiveness of sins (cf. 13:28-39), which could be a major further point about Paul's gospeling. Forgiveness is what is granted to those who respond properly to the gospel. Tucked between Paul's Pisidian Antioch gospeling and what he declared on the Areopagus is Acts 15's decision 
that Gentile believers and repenters did not have to be circumcised. Paul played some role in that debate, but the bigger role he had was to distribute the Jerusalem Council's (15:2235) decision to the churches outside Jerusalem that circumcision is not required for conversion.

Neither at Pisidian Antioch nor on the Areopagus does Paul call his audience to baptism. Paul himself was baptized (cf. 8:18; 22:16) and in other settings baptism followed response to the gospel $(16: 15,33 ; 18: 8 ; 19: 3-5)$. But it is a strange curiosity that Paul does not demand baptism in these two gospeling sermons. And neither does he call them to be circumcised - a sign that the Paul of Acts goes along with the compromise in Acts 15.

Summaries of Paul's gospeling shed light on the big picture of Paul's gospel (20:20-21, 25-27; 26:17-18; 26:19-23). The focus of Paul's gospel is summed up in Acts 28:20. Paul's gospel from these summaries is (1) about the Story of Israel coming to fruition in the Story of Jesus (cf. 26:22-23) and (2) this Story of Jesus is shaped through the crucifixion but especially his vindicating resurrection, and (3) the appropriate response is to repent and believe in the Lord Jesus.

\section{Gospeling in Acts and Gospeling Today}

The task of evangelism ('gospeling') is no less demanding and difficult today than it was in the time of Peter and Stephen and Paul. It is also in no less need of creative adaptations to audience. Perhaps what we need more of is the boldness (Acts 2:29; 4:13, 29, 31; 28:31) that came upon them through a fresh blowing of the Spirit. Perhaps the absence of resurrection theology in much of gospeling today is to blame for the lack of boldness. We need to recover more of the early Christian resurrection gospel and we need less of the theodicy-like focus Anselm and the Reformers gave to atonement theories. What then is the gospel?

\subsection{The Gospel according to Acts}

Acts leads me to conclude that the gospel is (1) the narration of the Story of Jesus - his life, his death, his resurrection, his exaltation, and his coming again - in the context of the Story of Israel, and Luke's ending of Paul's life by attempting to persuade the Jews that their Story was fulfilled in Jesus shows just how important this theme was (cf. 28:17-28). (2) It involves an exalted Christology where Jesus is seen as suffering, ruling, and judging. (3) Gospeling is incomplete until it summons those who hear the gospel to repentance, to faith in Jesus Christ, and to baptism. (4) That gospel promises forgiveness and the gift of the Holy Spirit.

\subsection{The Gospel of Acts and Modern Day Gospeling}

In order to discern the importance of the gospeling of Acts for modern day gospeling it is important to compare the two (5.2.1) and to note significant developments in gospeling in the history of the church (5.2.2) before concluding with a correction of present day gospeling (5.2.3).

\subsubsection{Comparisons}

Perhaps the most astounding observation is that the Book of Acts has no atonement theology at work in the narration of the death of Jesus in gospeling (but cf. 20:28), and this 
stands in bold contrast to the gospel summary of 1 Corinthians 15:3. We have death, we have Scripture, and we have forgiveness of sins - after the narration of resurrection and exaltation - but we have no reflection in these gospeling events on atonement. It cannot be said, therefore, that the gospeling sermons of Acts are based on the early Christian gospel tradition of 1 Corinthians 15 . They seem to be independent, and one might say that Luke's theology ran alongside, but not within, that creedal perception of the gospel.

Neither Peter nor Paul focus on God's wrath, and they don't describe redemption as an escape from hell. But judgment is not far away from their gospeling work. Just what the 'problem' is that they see resolved in the gospel is worthy of serious re-consideration. One can infer from the promises - forgiveness and the gift of the Holy Spirit - that the problems were sin and the absence of God's power. But we would be mistaken to see this in purely individualistic terms. Peter's summary in Acts 5:29-32 sees forgiveness for 'Israel.,

A third comparison comes from the modern to the ancient: there is much to-do today about the anti-imperial slant of Luke's theology and Paul's theology. There is not, however, really much about this in either Peter or Paul, though one might argue that the blame the gospelers lay on the temple establishment is anti-imperialism. Paul's address at the Areopagus, bringing up as it does the idols, might be used to further the anti-imperial agenda of Paul and see it as inherent to the gospel. I think here of Horsley (2002) and Wright (2005:59-82), but I'm not convinced the anti-imperial theme was nearly as conscious as these scholars are suggesting.

\subsubsection{Developments}

Gospeling, as the pages of the New Testament unfold and as the Church's tradition takes shape, involves at least these features:

- First, there is a reason why the first four books of the New Testament are called Gospels. Mark, who I believe is at the bottom of the Gospels' well, called his book a 'gospel' and, whether or not that was the reason, the Church called Matthew, Mark, Luke and John gospels. They did because the gospel is the narrative of Jesus' Story and therefore the four Gospels are gospeling events. We gospel whenever we read, teach, or preach the Gospels (McKnight 2007:142-148). The four Gospels, therefore, take Paul's classic gospel propositional lines of 1 Corinthians 15:1-8 (20-28?) and fill them in.

- Second, both Eucharist and Baptism are gospeling events (McKnight 2007:149-156). I appeal here to Paul in 1 Corinthians 11:26. Eucharistic gospeling occurs on the part of the ingester of the bread and wine - that person, in appropriating the Lord's body and blood, proclaims $(\kappa \alpha \tau \alpha \gamma \gamma \varepsilon \dot{\lambda} \lambda \omega)$ the Lord's death until the coming of Christ. And Romans 6:1-11 clearly connects baptism to both the death and resurrection of Jesus Christ. Baptism embodies and therefore announces the gospel - it tells the Story of Jesus' death and life.

- Third, the classic creeds of the Church, the Apostles' Creed and the Nicene Creed and the Chalcedonian Definition suspend their ideas on a narrative re-telling of the Story of Jesus. These creeds are, therefore, gospeling. I maintain the view that teaching the creeds is teaching the gospel and I maintain that fidelity to these creeds is required to be faithful to the gospel.

7 Another comparison comes to mind: the foundation for much of gospeling today is that God loves us, and this has been made famous in evangelists like Billy Graham. One sometimes hears this more in terms of 'grace' than love, but the point remains the same: gospeling begins with the comforting message that God loves us. But that has nothing to do, though it can be assumed, in the gospeling texts of Peter and Paul. 
- Fourth, the church calendar - in its various forms and in various ways - gospels the gospel. If it begins with Advent and then prepares for Good Friday/Easter by teaching the life and teachings of Jesus, and then on to Pentecost, and in some traditions opens up during summer for more looks at the life of Jesus, then we can say that the calendar is a form of gospeling because it is designed to tell the Story of Jesus.

\subsubsection{Corrections}

Far too much of gospeling in the church today is no more than three quarters of the gospel we find in the Book of Acts: we get plenty of narrative about Jesus, plenty of promise of forgiveness (and heaven too), plenty of Christology, but not enough of the call to respond with repentance and faith. Baptism, alone, does not do because baptism is not alone in the earliest gospeling. Baptism brings to fruition one's faith in the Lord Jesus and one's repentance - it is a death to sin and a new life to Christ. At work in both Peter's hermeneutic of reading Israel's Story and the Story of Jesus is a potent, if comparatively primitive, Christology. If one reads the Story of Jesus as the climax of the Story of Israel, one comes to Peter's Christology. Both Acts 2:36 and 10:36-38 bring Peter's hermeneutic to this point: Jesus of Nazareth, the one who lived and died and who was raised, is both Messiah of Israel and Lord of Israel (and the whole world).

\section{BIBLIOGRAPHY}

Achtemeier, PJ, Green JB \& Thompson, MM 2001. Introducing the New Testament - Its Literature and Theology. Grand Rapids: Eerdmans.

Alexander, L 1999. The Acts of the Apostles as an Apologetic Text, in Edwards, MJ, Goodman, M, Price, S \& C Rowland (eds.) 1999. Apologetics in the Roman Empire: Pagans, Jews, and Christians, 15-44. Oxford: Oxford University Press.

Barrett, CK 1994. Acts 1-14. London: T \& T Clark International. (ICC).

Barrett, CK 1998. Acts 15-28. London: T \& T Clark International. (ICC).

Biddle, M 2005. Missing the Mark - Sin and Its Consequences in Biblical Theology. Nashville: Abingdon.

Bock, DL 2007. Acts. Grand Rapids: Baker Academic. (ECNT).

Bosch, DJ 1991. Transforming Mission - Paradigm Shifts in Theology of Mission. New York: Orbis Books. (American Society of Missiology Series).

Brown, C 1992. Historical Jesus, in Green, JB, McKnight, S, \& Marshall, IH (eds.) 1992. Dictionary of Jesus and the Gospels, 325-341. Downers Grove: InterVarsity Press.

Bruce, FF 1988. The Book of the Acts. Rev. (ed.) Grand Rapids: Eerdmans. (NICNT).

Bruce, FF 1974. The Speeches in Acts - Thirty Years After, in Banks, R (ed.) 1974. Reconciliation and Hope, 53-68. Exeter: Paternoster.

Conzelmann, H 1960. The Theology of St. Luke. New York: Harper \& Row.

Dunn, JD 2003. Jesus Remembered. Vol 1. Grand Rapids: Eerdmans. (Christianity in the Making).

Dunn, JD 2008. Beginning from Jerusalem. Vol 2. Grand Rapids: Eerdmans. (Christianity in the Making). 
Ferguson, E 2009. Baptism in the Early Church - History, Theology, and Liturgy in the first Five Centuries. Grand Rapids: Eerdmans.

Frost, M 2006. Exiles - Living missionally in a Post-Christian culture. Peabody: Hendrickson Publishers.

Greene, C \& M Robinson 2008. Metavista - Bible, Church and Mission in an Age of Imagination. Colorado Springs: Authentic. (Faith in an Emerging Culture Series).

Horsley, R 2002. Jesus and Empire: The Kingdom of God and the New World Disorder. Minneapolis: Fortress Press.

Jervell, J 1996. The Theology of the Acts of the Apostles. Cambridge: Cambridge University Press. (New Testament Theology).

Johnson, LT 2006. The Acts of the Apostles. Colledgeville: Liturgical Press (Sacra Pagina Series).

Kee, HC 1997. To Every Nation under Heaven. The Acts of the Apostles. Harrisburg: Trinity Press International. (The New Testament in Context).

Ladd, GE 1974. A Theology of the New Testament. Cambridge: Lutterworth Press.

Marshall, IH 1980. Acts. Grand Rapids: Eerdmans. (Tyndale New Testament Commentaries).

McKnight, S 2002. Turning to Jesus: The Sociology of Conversion in the Gospels. London: Westminister Press.

McKnight, S 2007. A Community Called Atonement. Nashville: Abingdon Press. (Living Theology).

McLaren, BD 2006. The Secret Message of Jesus. Uncovering the Truth that could change Everything. Nashville: W Publishing Group.

McLaren, BD. 2007. Everything Must Change: When the World's Biggest Problems and Jesus' Good News Collide. Dallas: Thomas Nelson.

Meek, JA 2008. The Gentile Mission in Old Testament Citations in Acts. Text, Hermeneutics, and Purpose. London: T \& T Clark International. (Library of New Testament Studies).

Nel, MJ 2009. The emerging missional church, in Du Plessis, J, Orsmond, E \& HJ van Deventer (reds) 2009, 35-48. Missionary Perspectives in the New Testament. Wellington: Bible Media.

Peters, T 1994. Sin: Radical Evil in Soul \& Society. Grand Rapids: Eerdmans.

Plantinga, C 1995. Not the Way It's Supposed to Be - A Breviary of Sin. Grand Rapids: Eerdmans.

Polhill, JB 1992. Acts. Nashville: Broadman \& Holman Publishers. (The New American Commentary).

Ridderbos, H 1975. Paul. An Outline of his Theology. Grand Rapids: Eerdmans.

Stark, R 1997. The Rise of Christianity: How the Obscure, Marginal, Jesus Movement Became the Dominant Religious Force in the Western World in a Few Centuries. Francisco: HarperCollins.

Thiselton, AC 2007. Hermeneutics of Doctrine. Grand Rapids: Eerdmans.

Viola, F \& G Barna 2008. Pagan Christianity? Exploring the Roots of Our Church Practices. Carol Stream: Tyndale. 
Wilckens, U 1974. Die Missionsreden der Apostelgeschichte: Form- und traditionsgeschichtliche Untersuchungen. Neukirchen-Vluyn: Neukircherner Verlag. (Wissenschaftliche Monographien zum Alten und Neuen Testament).

Witherington, B 1997. The Jesus Quest - The third search for the Jew of Nazareth. $2^{\text {nd }}$ ed. Downers Grove: Inter-Varsity Press.

Wright, CJH 2006. The Mission of God - Unlocking the Bible's grand narrative. Nottingham: Inter-Varsity Press.

Wright, NT 2003. The Resurrection of the Son of God. Vol. 3. Minneapolis: Fortress Press. (Christian Origins and the Question of God).

Wright, NT 2005. Paul. In Fresh Perspective. Minneapolis: Fortress Press.

Wright, NT 2008. Surprised by Hope: Rethinking Heaven, the Resurrection, and the Mission of the Church. New York: HarderOne.

Wright, NT 2009. Justification: God's Plan \& Paul's Vision. London: SPCK. 